\title{
DEVELOPMENT OF THE CITY PUBLIC SERVICE MODEL ON THE BASIS OF INTEGRATED TRANSPORT FLOW INDICATORS
}

\author{
Nataliya Kablak ${ }^{1}$ \\ nataliya.kablak@gmail.com \\ Jolana Golik ${ }^{1}$ \\ Iryna Kutsyna ${ }^{1}$ \\ Nadia Kis ${ }^{1}$ \\ Yevgeniy Vodovozov ${ }^{2}$ \\ Oleksii Palant ${ }^{2}$ \\ ${ }^{1}$ Department of city building and economy \\ Uzhgorod National University \\ 3 Narodna sq., Uzhhorod, Ukraine, 88000 \\ ${ }^{2}$ Department of business economics and business administration \\ O. M. Beketov National University of Urban Economy in Kharkiv \\ 28 M. Bazhanov str., Kharkiv, Ukraine, 61002
}

\begin{abstract}
The problem of modeling public services based on architectural and planning decisions is considered, the role of traffic in the formation of a model of city services is analyzed. An integrated criterion for the quality of public services is proposed. A method has been developed for determining segmented public services taking into account the transport areas of the city, which will make it possible to evenly disperse public service centers. The basis is a socio-planning organization, as a material-spatial system containing anthropogenic and natural components - the territory and institutions where the functional processes that take place in the urban planning environment take place. The described model has certain versatility, and is simultaneously suitable for characterizing various categories of service institutions. Thus, the task of optimizing the quality of public services in the city is reduced to a mathematical model for which, by setting the basic design criteria, the optimal result can be obtained.

On the basis of a questionnaire survey and analysis of statistical data, calculation of traffic intensity, the demand and supply of the level of public services pre studied. The structural elements of this model: population, territory, transport and service institutions, are in dialectical interaction, which is described by the mathematical model in this study. The model is based on the calculation of the minimum population in the service area, which allows to have i-th type establishments using the social potential method, as well as a graph-analytical method in determining the optimal location of service institutions in the city.

As a result of the research, a conceptual model of public services for cities is built, a layout of supermarkets in the territory of Uzhhorod and distribution of service areas of these institutions is proposed. This optimization will ensure uniform domestic servicing of the territory, optimal performance indicators of service establishments and minimum average service radii of points.

Keywords: public services, model of public services, community services, criteria for service conditions.
\end{abstract}

DOI: $10.21303 / 2461-4262.2019 .001075$

\section{Introduction}

In the conditions of intensive urban development, the problem of streamlining transport services for the population is gaining priority. The basis for the improvement and development of the public service network is customer satisfaction. To provide structural units with services that would form an independent network at the micro-district level and, at the same time, be a full-fledged component of the service network at the highest levels, a model for optimizing the structure of the city's transport service based on interaction with public facilities is proposed. A feature of the statement of the problem of determining the optimal placement of service facilities is that it is necessary to take into account the spatial relationships between service points and points carried out using transport modeling. Communication data is determined by their location on the transport network and the terrain, which in the conditions of significant slopes significantly affects the choice of route. 
So, the rapid development of requirements for the level and quality of service dictates the need to increase the area for public services; and the growing level of motorization in the city (299.5 cars/thousand inhabitants as of 2018) necessitates the expansion of the roadway.

The result of solving the problem depends on a number of factors - the terrain, population density, planning and functional structure of the city.

The task of transport modeling and public services relates to the problems of mathematical and simulation modeling. There are many methods for determining the level of public services, described in [1-3]. As shown in [2-4], the structure of the cultural and public services network of public territories is examined in terms of the compliance of enterprises and institutions that form it with the levels of the planning system of the city and the region and the correspondence between the system of public service centers of the region and the city is revealed. But the city-planning aspects of the interaction of the traffic flow with the network of service institutions have not been analyzed and compared, as indicated in $[5,6]$.

The analysis of modern scientific publications on flow modeling shows that the study and application of the tasks of determining the level of public services in combination with simulation models of population movement is relevant $[7,8]$. So, in $[9,10]$ calculations of public services are proposed, taking into account the population and inter-district relations, which allow to present the interaction of service institutions in the form of graph theory. Such methods, as a rule, allow local vector tasks within the same transport service area. The work [11, 12] contains fuzzy analogues of methods for determining the logistic estimates of transport services, which allow taking into account various types of service institutions. The possibility and methods of using integrated transport indicators are shown in [14-16].

Today in the world there are dozens of software products for macro-modeling of traffic flows, for example Tmodel2, Cube, Emme/4, Transcad, Transnet, Visum [5, 9]. Using these software systems, transport models are built in cities such as New York, Los Angeles, London, Paris, Milan and others. The model of the transport network of almost all of Europe from the borders of the CIS to the Atlantic Ocean is constructed.

The most detailed (with the largest number of elements) transport model in the world is the German transport model made in PTV Vision VISUM. In addition, a transport model of Switzerland has been developed and also includes neighboring European countries as external regions.

In recent years, several Russian and Ukrainian cities have also developed transport models using PTV Vision VISUM software and are now successfully operating them on the basis of $\mathrm{A}+\mathrm{C}$ Ukraine, in particular, Kyiv, Lviv, Ivano-Frankivsk, Uzhhorod.

The aim of research is development of an integrated socio-planning model based on transport modeling to improve public services when using the results of expert surveys when forecasting and applying new service facilities.

To achieve this aim, the following objectives are set:

- to perform an analysis of the structure and formation of the public service network of the city;

- to develop a transport model of the socio-planning structure of small and medium-sized cities in order to improve the level of public services;

- to analyze and evaluate methods for optimizing the existing social planning structure of the city, taking into account traffic flows.

\section{Statement and analysis of the public service problem depending on the module of transport accessibility}

To determine the optimal methods for the spatial organization of the network of public centers of the city, their structural analysis is carried out $[1,2]$. For this, two levels of organization are distinguished: local and citywide. At the local level, the organization of community centers is characterized by: the functional composition of the community center, and its planning structure. At the citywide level, the organization of community centers in the city system depends on the planning structure of the city, the natural features of the territory and the social habits of the population [6]. Its main characteristics include the place of the social center in the system of relations, the type of system-forming connections, the functional role of the social center [7]. 
The results of the study allow to state [3]:

1. The network of community centers is a system-forming component of the socially-planning structure of the city, therefore the issue of the location, composition and place of the community center in the hierarchical system of community centers is crucial in its organization.

2. The model of interaction between community centers at various levels forms the migration flows in the city.

3. The main characteristics of community centers at the local level is the functional composition, planning structure; in citywide - the place of the community center in the communications system, the type of backbone ties and the functional role of the community center.

All the characteristics of community centers directly or indirectly depend on the planning structure of the city, the natural features of the territory and the social habits of the population. These characteristics make it possible to clearly parameterize the structure, determine the basic principles and directions of operation.

The quality of public services is determined using the following criteria:

1) indicators of the service result;

2) indicators (criteria) of service conditions;

3) indicators of the service process;

4) indicators (criteria) of transport accessibility.

The organization of public services is connected with the determination of spatial values adapted to the scale of this movement. For this purpose, the territory of the city center should be subordinated to a certain value - the public service segment based on the module of transport accessibility [5] and with its help should find its spatial expression (Fig. 1).

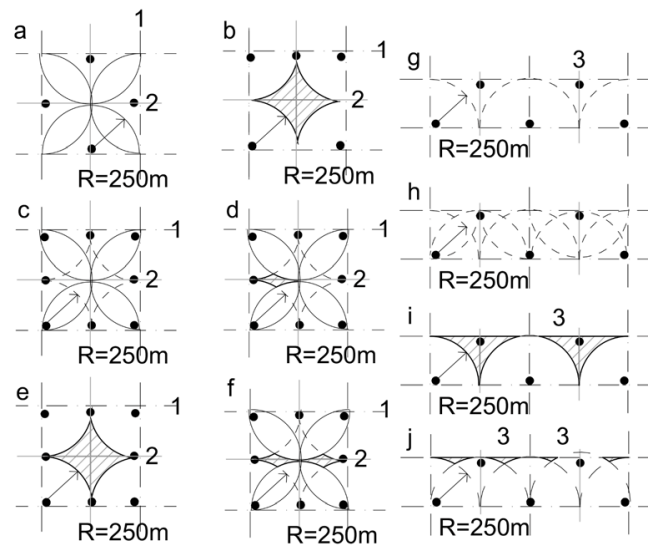

Fig. 1. The scheme of access radiuses based on the transport module:

$\mathrm{a}, \mathrm{b}, \mathrm{c}, \mathrm{d}$ - the full range of accessibility of service facilities; e, f, g-limited access to service facilities; $h, i, j-$ linear restriction of accessibility of service facilities

Option A illustrates the most appropriate arrangement of public transport stops, in which the distance to any focus of attraction on your territory is $250 \mathrm{~m}$.

Option B shows a solution in which four public transport stops are located in the corners of the center after $500 \mathrm{~m}$.

Option C shows the too frequent location of public transport stops (after $250 \mathrm{~m}$ ) with approaching the corners of the territory.

Option D shows a public transport service scheme from three sides, with a location module of $250 \mathrm{~m}$, where about $5 \%$ of the territory is produced, it has insufficient accessibility.

Option E makes it possible to service the area on both sides with public transport stops after $500 \mathrm{~m}$, where almost $20 \%$ remain unavailable, in variant $\mathrm{F} 10 \%$ are left unavailable.

Option $\mathrm{G}$ considers accessibility of a linear rectangular area with dimensions of 250 by $1000 \mathrm{~m}$. The location of public transport stops occurs after $500 \mathrm{~m}$ and ensures normal accessibility, option $\mathrm{H}$ is supposed to have a similar combination, but in a staggered manner. 
Options I, J provide for indicates an elongated linear structure, with the arrangement of stops at 500 and $250 \mathrm{~m}$, respectively, with a minimum percentage of inaccessibility for pedestrians.

\section{Study of analytical data of the city traffic flow}

During the study of analytical data, a structural-logical diagram of the interaction subsystems is developed. The subsystem "population" is represented by two blocks: structure and needs. The "structure" block reflects the basic structural characteristics of the "population" subsystem, namely: total population, age structure, marital status, employment structure, social structure, gender composition, and national composition.

The presentation of the "population needs" block is reduced to three categories - material, spiritual, and household needs - which makes it possible to clearly define the nomenclature of service institutions and to identify the frequency of occurrence of needs and their frequency.

"Territory" subsystem - characterized by blocks "structure of the territory"; and "transport potential of the territory". These blocks are described by a number of criteria and include: functional structure, planning structure, street-road network, departmental structure, administrative, source-cultural, spatial and other structures. The "transport potential of the territory" block describes the types of urban infrastructures - labor (tricks of labor attraction), socio-cultural, transport, engineering and others, as well as the degree of their influence on the spatial organization of the processes of vital activity of the population, on the development of environmental elements.

In total, 2339 respondents who provided information on 4880 trips of the previous day took part in the mobility survey of Uzhhorod. Of these, 111 respondents did not leave home. The model analyzed 100 districts, of which 83 in the city, 13 in the suburban areas, 4 border areas. According to the survey, the overall mobility rate for residents of Uzhhorod is 2.09 , that is, on average per day, residents of the city carry out 2 movements.

On average, there are 349 cars and 279 bicycles (including children) on the 1000 population of the city. At the same time, only more than half of the respondents who had cars in the household $(60 \%)$ used them to move on the previous day. The proportion of those who used the bike to move around the city from those who have at least one bike in the family is even less $-18 \%$.

In general, the cartogram of the passenger flows of individual and public transport can be viewed below, which forms the basic understanding of transport hubs, which includes pedestrian traffic.

In general, the distribution of priorities is similar: the majority uses private cars ( $43 \%$ and $32 \%$ in line), the second most popular is public transport (36\% and $25 \%$ in line). However, in terms of actual movement during the previous day, public transport is almost identical in popularity to walking $(24 \%)$, in contrast to the lower estimate of the share of walking in general practice $12 \%$, Fig. 2 [4].

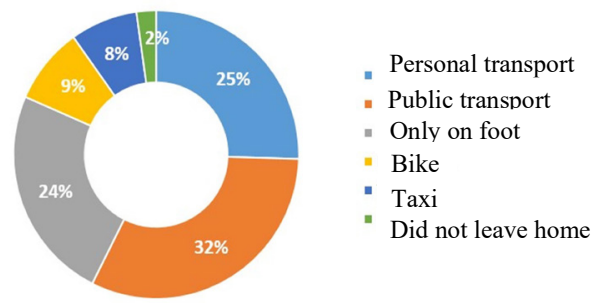

Fig. 2. Distribution of travel of the previous day for travel modes [4]

However, the data show that an identical share of bicycle users does not indicate the stability of a group of cyclists. In fact, considering exactly which modes the respondents used, determined the main mode of movement, it is noticeable that if for groups of users of public transport, personal transport and those who travel on foot, their mode of movement and really dominates among those used, almost half of those who usually use bicycles, in fact, for the polled day, it was only walking, another $15 \%$ used either public transport or did not leave home. While those who indicated usually did not leave their homes, they actually carried out trips and movements - one third of the movements - on foot and by public transport; $15 \%$ for personal cars and bicycles. 
When considering trips by gender, one can see that while public transport is used by representatives of both sexes relatively equally ( $26 \%$ and $24 \%$ for women and men, respectively), men use personal transport and bicycles more actively than women, while women more often than men, they walk or take a taxi (Fig. 3).

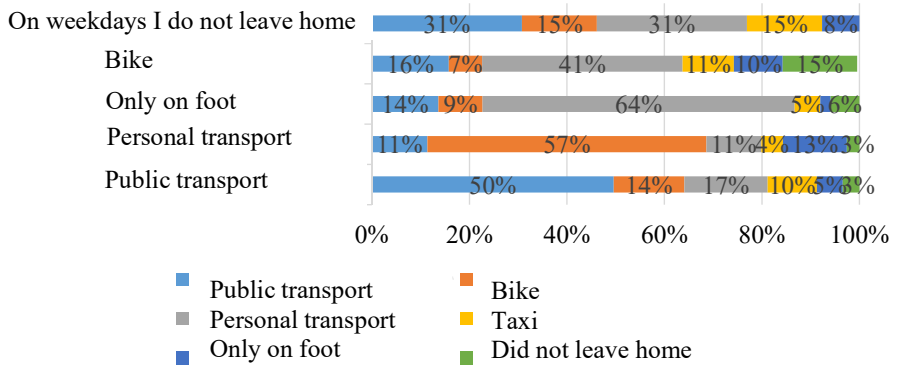

Fig. 3. The percentage distribution of movements in demand

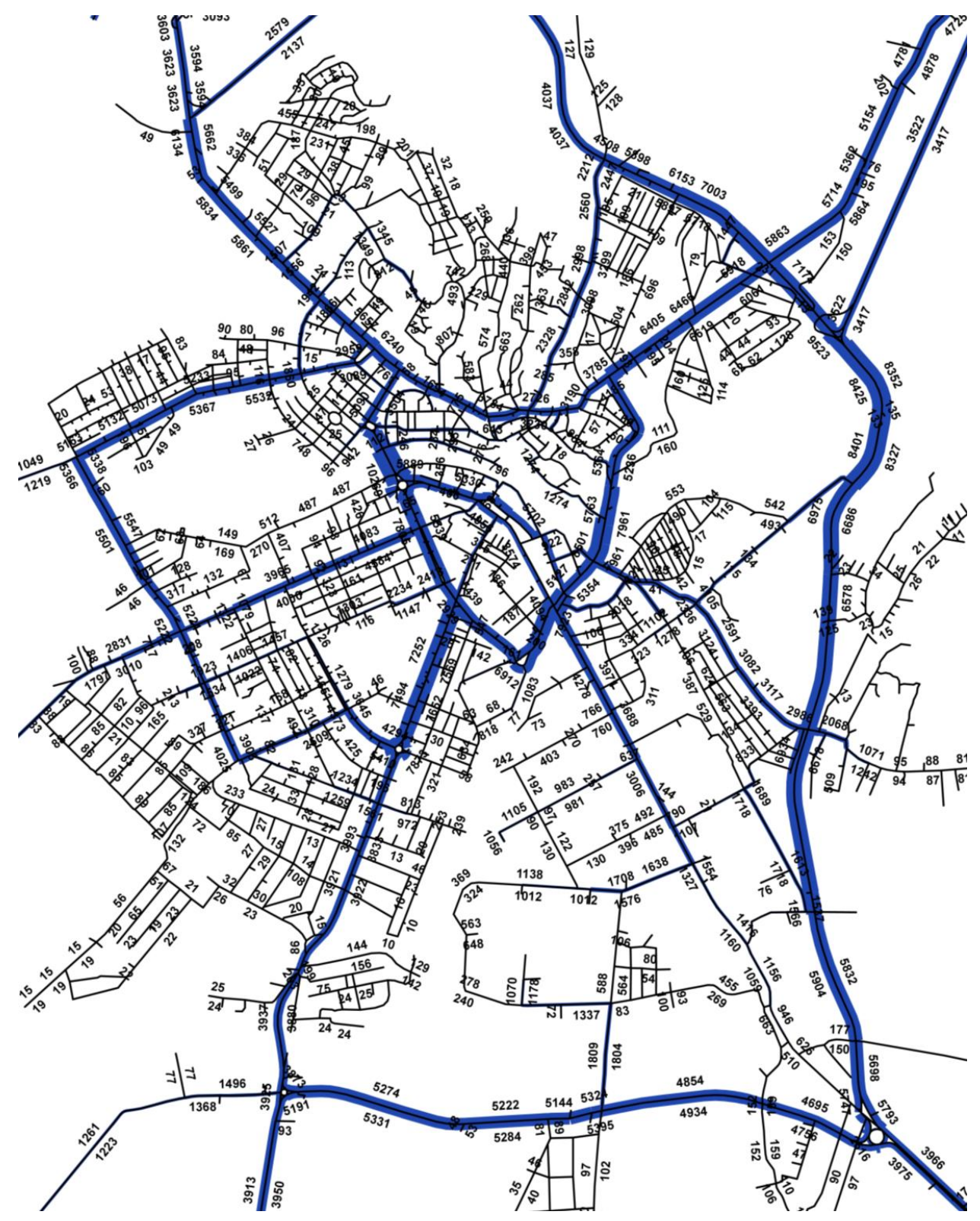

Fig. 4. Cartogram of traffic and pedestrian traffic 
When considering trips by gender, one can see that while public transport is used by representatives of both sexes relatively equally ( $26 \%$ and $24 \%$ for women and men, respectively), men use personal transport and bicycles more actively than women, while women more often than men, they walk or take a taxi (Fig. 5).

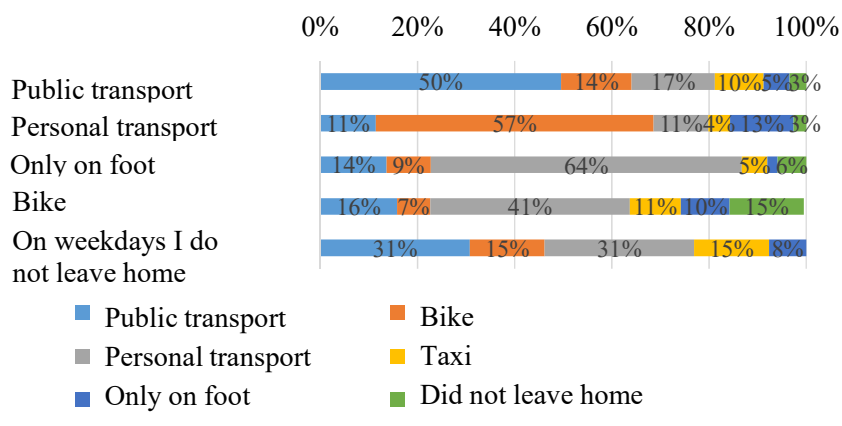

Fig. 5. The percentage distribution of movements in demand

The average trip duration for various modes of movement varies from 16 minutes for a taxi to 27 minutes for public transport, walking is within walking distance and averages $22 \mathrm{mi}-$ nutes (Fig. 6).

Public transport
Personal transport
Only on foot
Bike
Taxi

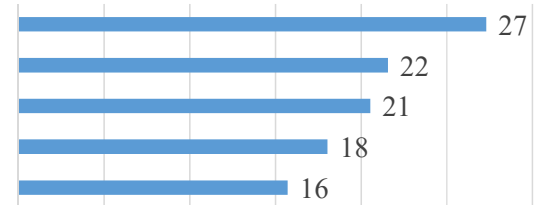

Fig. 6. The average duration of the trip for various modes of movement, min.

Distribution by layers of demand. Special attention should be paid to the goals for which pedestrian movements of the population of Uzhhorod are carried out. The separation between the goal of the starting point and the goal of the end is called the demand layers and in the analysis and development of the model the total number of trips was divided into 17 main layers of demand.

As it is possible to see, these statistics indicate that the largest share of pedestrian movements is made by Home-Other and Other-Home movements; almost half as much - moving to and from work; less represented are the movements between work and universities (Fig. 7, 8).

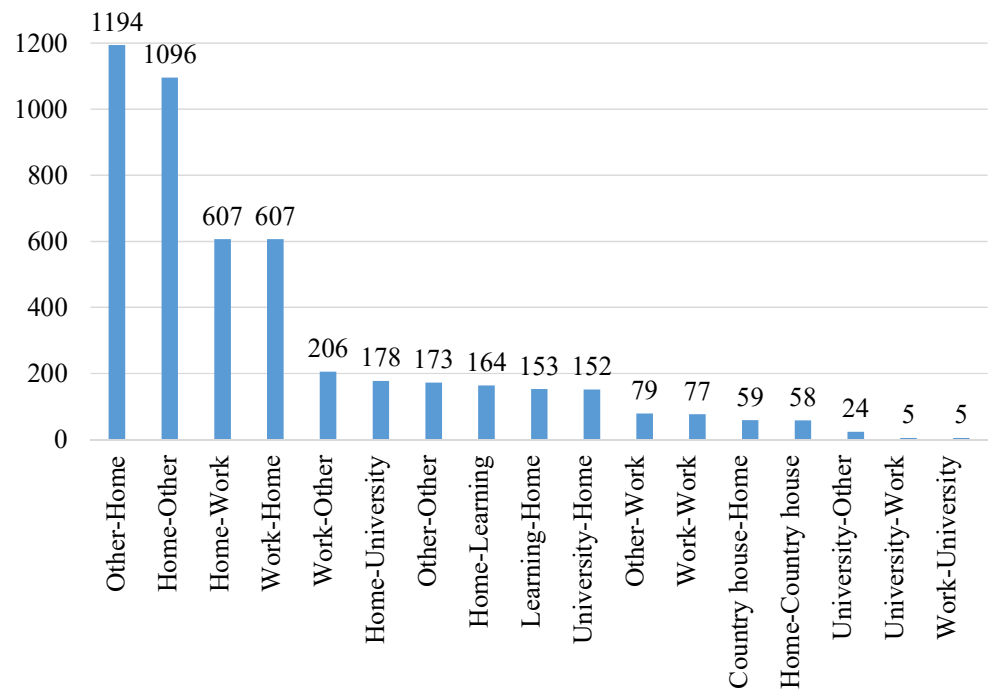

Fig. 7. The distribution of movements by layers of demand 


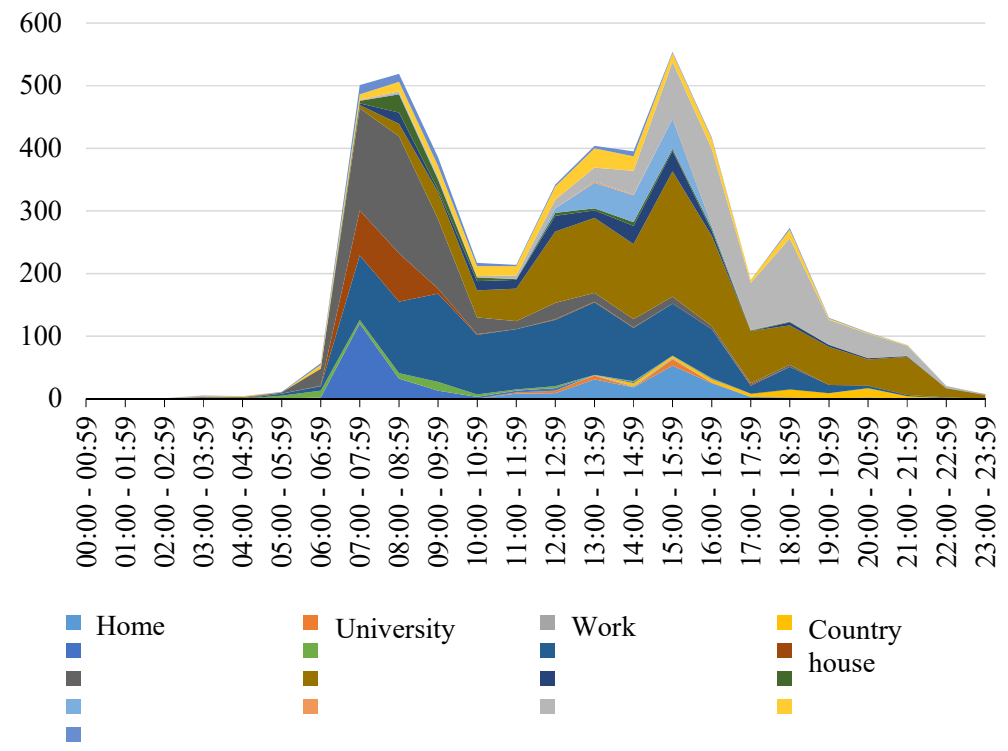

Fig. 8. Distribution of trips by different layers of demand by departure time, (quantity per hour)

\section{Experimental verification of research results}

To test the effectiveness of the model for optimizing the structure of the city's public services, a network of food stores - supermarkets - is calculated as the main structure-forming element [8-11].

Supermarket is a self-service store (shop) with a trading area from $400 \mathrm{~m}^{2}$ to $2499 \mathrm{~m}^{2}$ with an assortment of food and non-food items of more than 5 thousand assortment items [3].

This type of shops is periodic service establishments included in the community center of a residential area.

To facilitate the calculation, in all cases, let's assume that service centers are located only in settlement units.

The task is determination of the optimal quality of service:

$$
Q_{o p t}=Q\left(R, n, S_{i}, X\right),
$$

in the case of:

$$
R \rightarrow \min ; n \rightarrow n_{i} ; S_{c, m} \leq S_{i} ; X \rightarrow \min ,
$$

where $Q_{o p t}$ - optimal quality of service; $Q$ - quality of service; $R$ - the minimum average radius of service; $n$-population in the service area (to ensure the minimum capacity of the institution); $n_{i}$ - the minimum population in the service area, which allows to have establishments of the $i$-th type; $X=\left\{x_{1}, x_{2}, \ldots, x_{k}\right\}$ - set of points that need to be served; $S_{c . m}$ - residential area; $S_{i}$ - area of influence of service institutions of the $i$-th type of service.

The first step to solving the problem of improving the socio-planning organization of the average city is to analyze the territory, build a graph and select $X$ points where it is possible to place service establishments - centers of the graph. To do this, a breakdown of residential territories into residential zones is carried out - points that need to be provided with services. The boundaries of settlement zones are set depending on the required accuracy of calculations, the nature of development, and the level of the social planning unit. Consequently, this method provides for the collection of the following initial data for calculations: the directions of cultural and everyday gravitations in the city, the area of residential zones and the population density of these zones.

In accordance with the graph-analytical method, which is described in detail in [4], those points of the district are provided with service, the distances from which to the point under study on this road network are less than acceptable. For clarity, in Fig. 9 zones of influence of service 
institutions are approximated by circles, the area of which corresponds to the service area of these institutions. Each network point is assigned its own number.

Let the zone of influence of institution $x_{23}$ cover the territory of $\mathrm{M}^{4}$ with an area of $\mathrm{M}^{4}$, by analogy, it is possible to determine the values of $S_{26,27,28}^{\mathrm{M} 4}$. In addition, it is necessary to take into account that parts of the zones of influence of institutions intersect $-x_{23}$ and $x_{25}, x_{25}$ and $x_{26}, x_{26}$ and $x_{27}, x_{27}$ and $x_{25}$. The areas of these territories are denoted by $\mathrm{S}_{23,26}^{\mathrm{M} 4}, \mathrm{~S}_{25,26}^{\mathrm{M} 4}, \mathrm{~S}_{25,27}^{\mathrm{M} 4}, \mathrm{~S}_{26,27}^{\mathrm{M} 4}$ in accordance.

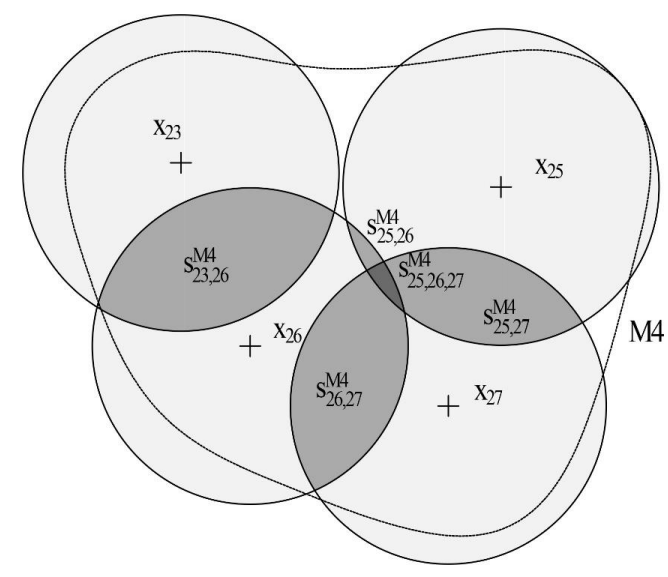

Fig. 9. Deterministic statement of the problem of rational choice of the influence zone of service institutions

On the territory there are sections of overlapping zones of influence of institutions $x_{25}, x_{26}$, $x_{27}$, which is denote as $S_{25,26,27}^{M 4}$.

It follows that the restriction can be written as a polynomial function:

$$
\begin{aligned}
& S_{23}^{M 4} x_{23}+S_{26}^{M 4} x_{26}+S_{27}^{M 4} x_{27}+S_{25}^{M 4} x_{25}-S_{23,26}^{M 4} x_{23} x_{26}- \\
& -S_{27,25}^{M 4} x_{27} x_{25}-S_{25,26}^{M 4} x_{25} x_{26}-S_{25,26,27}^{M 4} x_{25} x_{26} x_{27} \geq S_{t o t}
\end{aligned}
$$

An analysis of the resulting inequality (3) shows that the problem formulated is reduced to a nonlinear programming problem. As a limitation, it should be noted that the variables $x_{23}, x_{25}, x_{26}$, $x_{27}$ can take binary values. The essence of the transformation is introducing also Boolean auxiliary variables, which replace the terms of the original polynomial. So, the auxiliary variable for the $k$-th term of polynomial (3) will have the form:

$$
y_{k=\prod_{j=1}^{n_{k}} x_{j}}
$$

where $n_{k}-$ the number of factors in the $k$-th term. To ensure the conditions $y_{k}=1$ for all $x_{j}=1$ and $y_{k}=0$ otherwise, the following conditions are superimposed on each variable $y_{k}$ :

$$
\begin{gathered}
\sum_{j=1}^{n_{k}} x_{j}-\left(n_{k}-1\right) \leq y_{k}, \\
\frac{1}{n_{k}} \sum_{j=1}^{n_{k}} x_{j} \geq y_{k} .
\end{gathered}
$$

Thus, these restrictions make it possible to take into account the radii of accessibility of service facilities of each $\mathrm{x}$-district when the k-th term of the initial polynomial changes.

The centers of the polynomial graph must satisfy a number of criteria:

1. Have a minimum average radius of accessibility that does not exceed the normative for this type of service.

2. Serve the maximum number of points. 
3. Own the minimum population in the service area, which allows to have establishments of the i-th type.

From this initial set of points, it is necessary to select the minimum number of $\mathrm{N}$ positions that will ensure full service to the population of a given territory $[11,12]$. If residential areas are fully provided with services, then the condition is met:

$$
S_{c . m} \leq S_{i}
$$

where $S_{c . m}$ - the area of residential territories; $S_{c . m}$ - the area of influence of service institutions of the $i$-th type of service.

Let's suppose that within the city, with a residential area $S_{c . m}$, there are M positions suitable for placement of service institutions of a certain type of service.

Let's set the vector $X=\left\{x_{1}, x_{2}, \ldots, x_{k}\right\}$, with $X=\left\{x_{1}, x_{2}, \ldots, x_{k}\right\}$ if the k-th position is an establishment, and $X=\left\{x_{1}, x_{2}, \ldots, x_{k}\right\}$ if not.

Inter-main territory is represented as a set of positions $M$, which includes all points on it. Then, it is necessary to choose such a set of positions $N(N$ is $M, N \rightarrow \min )$ at which all points of all residential territories will be in the zone of influence of at least one institution.

It is necessary to choose the minimum number of locations for service facilities in a limited area (residential area, residential territory) so that the zones of influence of the facilities cover the area.

Preliminary data obtained from the initial parameters are listed in Table $\mathbf{1}$ and plotted on the calculation scheme (Fig. 8). Having obtained preliminary results, it is possible to proceed to analyze the existing quality of service for a given network, and bring it to the optimum.

In accordance with the graph-analytical method, those points of the district are provided with service, the distances from which to point $\mathrm{n}$ on this road network are less than acceptable (in this case, this value is $1500 \mathrm{~m}$ ). Accordingly, it is easy to determine at what points it makes no sense to place the centers, and at what location of the institution, the service will be provided. Graph-analytical analysis shows that there are a number of points where it would be appropriate to place a supermarket. It is necessary to choose the best option (Fig. 11).

Table 1

Studying the needs of points and population flows

\begin{tabular}{|c|c|c|c|c|c|}
\hline Point & Area, ha & Density, people/ha & Population, people & $\begin{array}{l}\text { The norm of require- } \\
\text { ments of the item, sq. } \mathrm{m} \text {. } \\
\text { of retail space }\end{array}$ & $\begin{array}{c}\text { The flow of population } \\
\text { from the point to } \\
\text { the service, people }\end{array}$ \\
\hline 1 & 2 & 3 & 4 & 5 & 6 \\
\hline $\mathrm{X} 1$ & 71 & 28 & 1988 & 139 & 901 \\
\hline $\mathrm{X} 2$ & 75 & 28 & 2100 & 147 & 952 \\
\hline $\mathrm{X} 3$ & 44 & 28 & 1232 & 86 & 559 \\
\hline $\mathrm{X} 4$ & 30 & 30 & 900 & 63 & 408 \\
\hline $\mathrm{X} 5$ & 32 & 28 & 896 & 63 & 406 \\
\hline X6 & 48 & 28 & 1344 & 94 & 609 \\
\hline $\mathrm{X} 7$ & 47 & 28 & 1316 & 92 & 597 \\
\hline $\mathrm{X} 8$ & 37 & 30 & 1110 & 78 & 503 \\
\hline X9 & 45 & 28 & 1260 & 88 & 571 \\
\hline $\mathrm{X} 10$ & 47 & 25 & 1175 & 82 & 533 \\
\hline $\mathrm{X} 11$ & 66 & 25 & 1650 & 116 & 748 \\
\hline $\mathrm{X} 12$ & 28 & 30 & 840 & 59 & 381 \\
\hline $\mathrm{X} 13$ & 61 & 30 & 1830 & 128 & 830 \\
\hline $\mathrm{X} 14$ & 32 & 25 & 800 & 56 & 363 \\
\hline $\mathrm{X} 15$ & 68 & 25 & 1700 & 119 & 771 \\
\hline
\end{tabular}


Continuation of Table 1

\begin{tabular}{|c|c|c|c|c|c|}
\hline 1 & 2 & 3 & 4 & 5 & 6 \\
\hline X16 & 44 & 22 & 968 & 68 & 439 \\
\hline X17 & 47 & 22 & 1034 & 72 & 469 \\
\hline X18 & 64 & 77 & 4928 & 345 & 2234 \\
\hline X19 & 54 & 77 & 4158 & 291 & 1885 \\
\hline $\mathrm{X} 20$ & 38 & 77 & 2926 & 205 & 1327 \\
\hline $\mathrm{X} 21$ & 51 & 61 & 3111 & 218 & 1411 \\
\hline $\mathrm{X} 22$ & 31 & 61 & 1891 & 132 & 857 \\
\hline X23 & 29 & 61 & 1769 & 124 & 802 \\
\hline $\mathrm{X} 24$ & 42 & 77 & 3234 & 226 & 1466 \\
\hline $\mathrm{X} 25$ & 67 & 77 & 5159 & 361 & 2339 \\
\hline X26 & 48 & 61 & 2928 & 205 & 1328 \\
\hline $\mathrm{X} 27$ & 37 & 61 & 2257 & 158 & 1023 \\
\hline X28 & 40 & 77 & 3080 & 216 & 1397 \\
\hline X29 & 28 & 77 & 2156 & 151 & 978 \\
\hline X30 & 43 & 25 & 1075 & 75 & 487 \\
\hline X31 & 45 & 25 & 1125 & 79 & 510 \\
\hline X32 & 38 & 25 & 950 & 67 & 431 \\
\hline X33 & 30 & 25 & 750 & 53 & 340 \\
\hline X34 & 42 & 25 & 1050 & 74 & 476 \\
\hline X35 & 40 & 22 & 880 & 62 & 399 \\
\hline X36 & 23 & 22 & 506 & 35 & 229 \\
\hline X37 & 67 & 25 & 1675 & 117 & 759 \\
\hline X38 & 48 & 25 & 1200 & 84 & 544 \\
\hline X39 & 61 & 22 & 1342 & 94 & 608 \\
\hline
\end{tabular}

Today, the functioning of the urban public service network is taking place against the background of a low population density with a significant number of residential quarters and an uneven distribution of the population throughout the city. In some cases, there is a partial or complete absence of public services institutions.

An assessment of the level of public services in the city showed that only $34.5 \%$ of the territory is provided with proper service [7]. And although the level of provision with service institutions in the city as a whole is satisfactory, the situation in the districts is far from meeting the standards (Fig. 10). This indicates significant shortcomings in the functioning of the public services sector of the city and, accordingly, a decrease in the urban development quality of the territory.

It has been established that under these conditions of functioning of the city's public service system, there is a need to review the existing structuring of the territory, determine the priority criteria for structuring and distribute the territory of the city into self-sufficient structural elements against the background of social traditions that have developed.

Based on the described example, the effectiveness of the proposed model for optimizing the structure of public services is verified using the example of a grocery store network throughout the city. The block diagram of decision making is shown in Fig. 12.

At the first stage, an analysis of the existing public service network is carried out, the compliance of residential areas of each district of the city with the requirements of the regulatory literature is assessed, residential areas are divided into residential areas - points that need to be provided with services. The boundaries of settlement zones are set depending on the required accuracy of calculations, the nature of development, and the level of the social planning unit. Each network point is assigned its own number. The following initial data are collected for the calculations: the 
directions of cultural and domestic gravitations in the city, the area of residential zones and the population density of these zones [3].

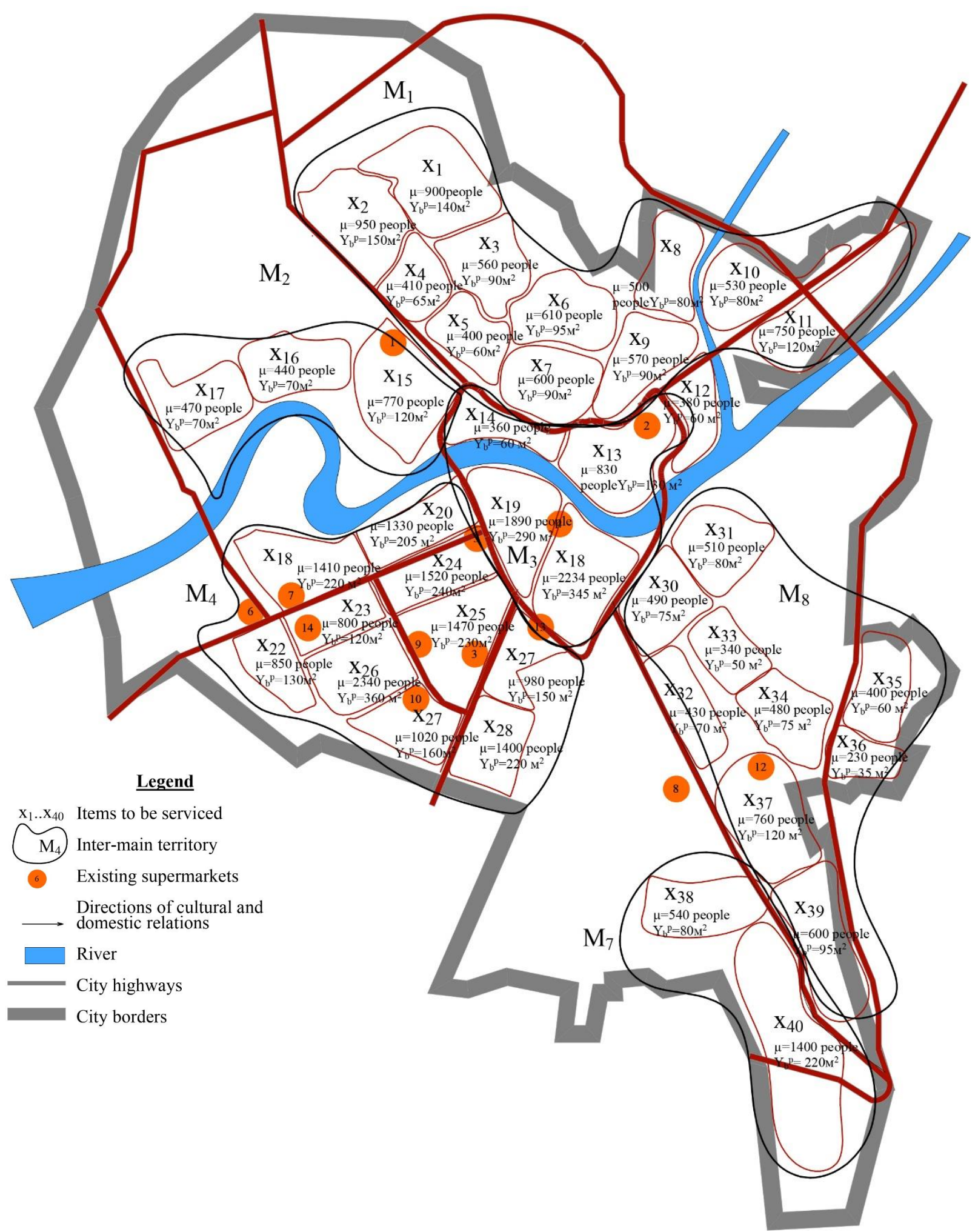

Fig. 10. The estimated distribution pattern of cultural and domestic relations in the territory of Uzhhorod 


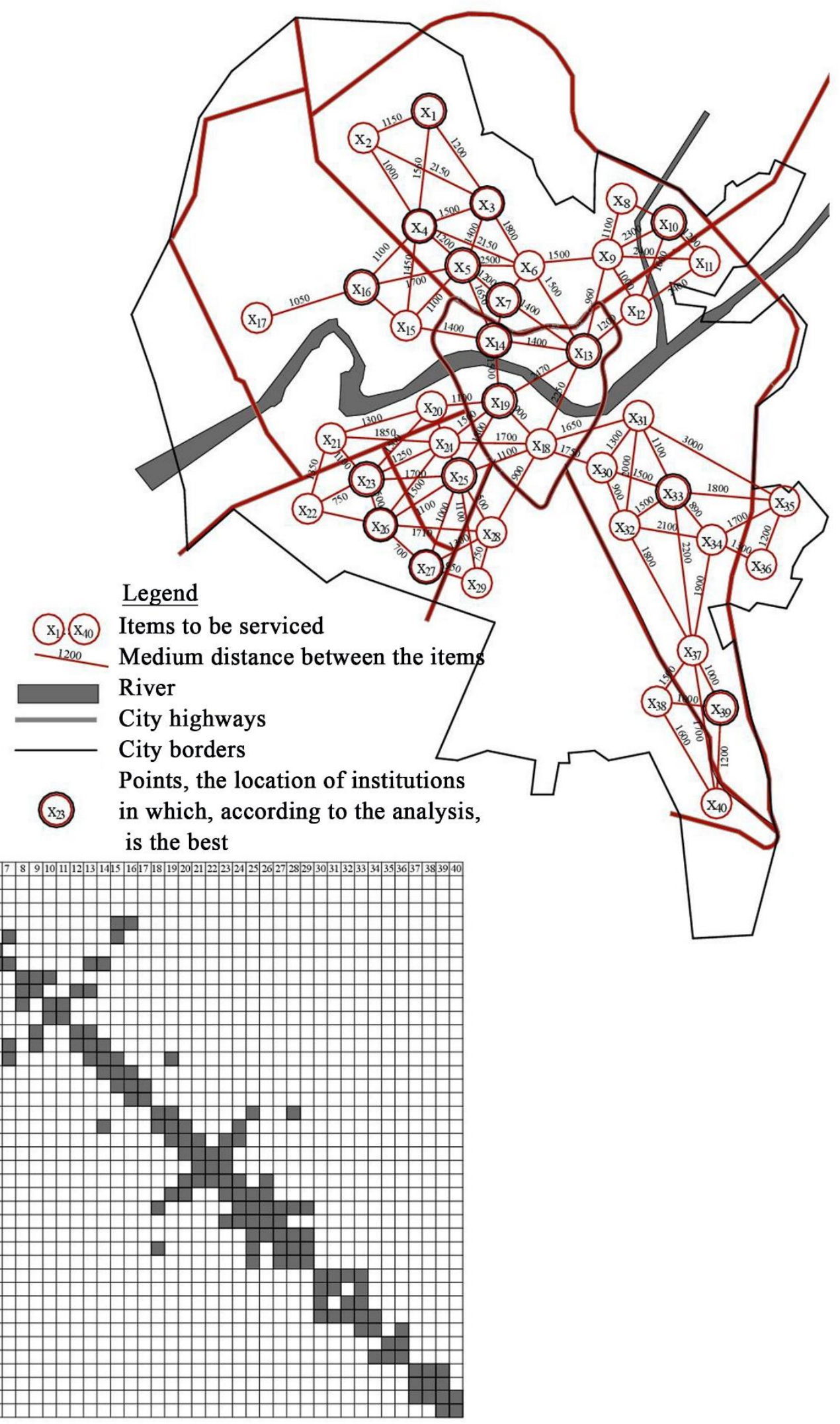

Fig. 11. The calculation scheme for determining the optimal placement of supermarkets in the territory of Uzhhorod using the graph-analytical method 


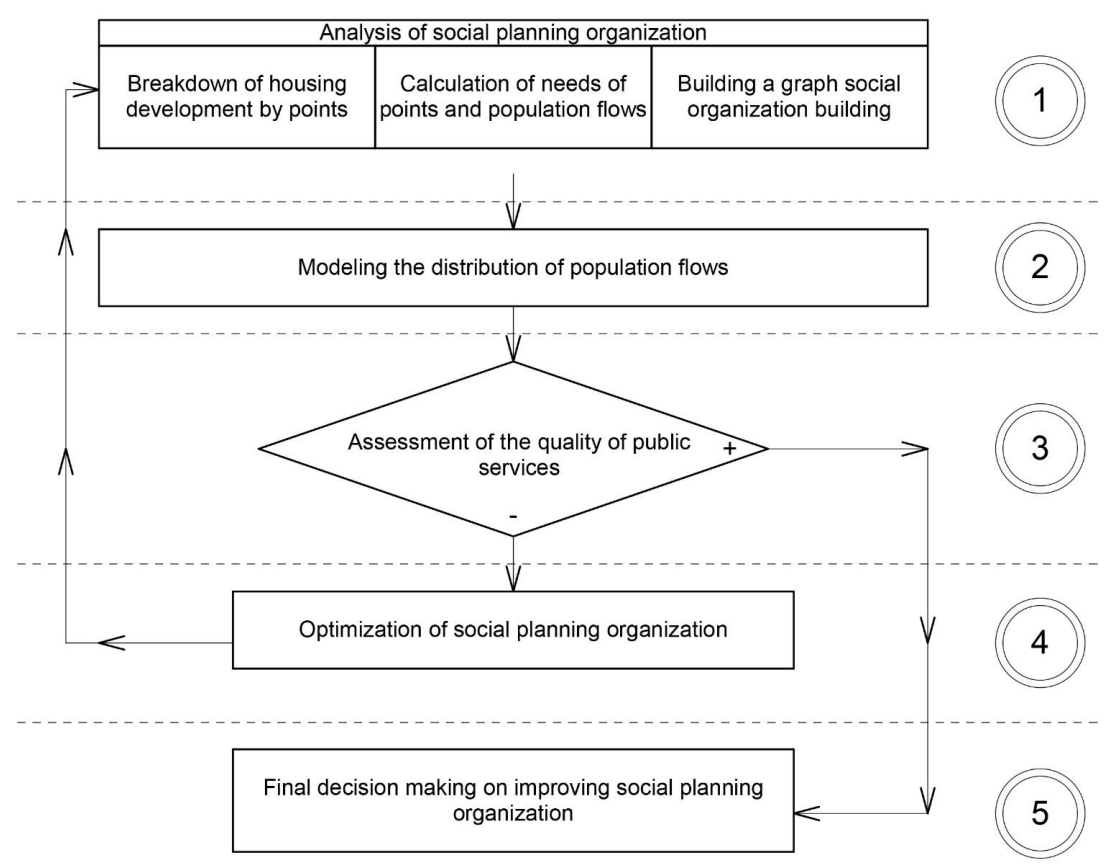

Fig. 12. The decision-making block diagram for improving the socio-planning organization of the average city

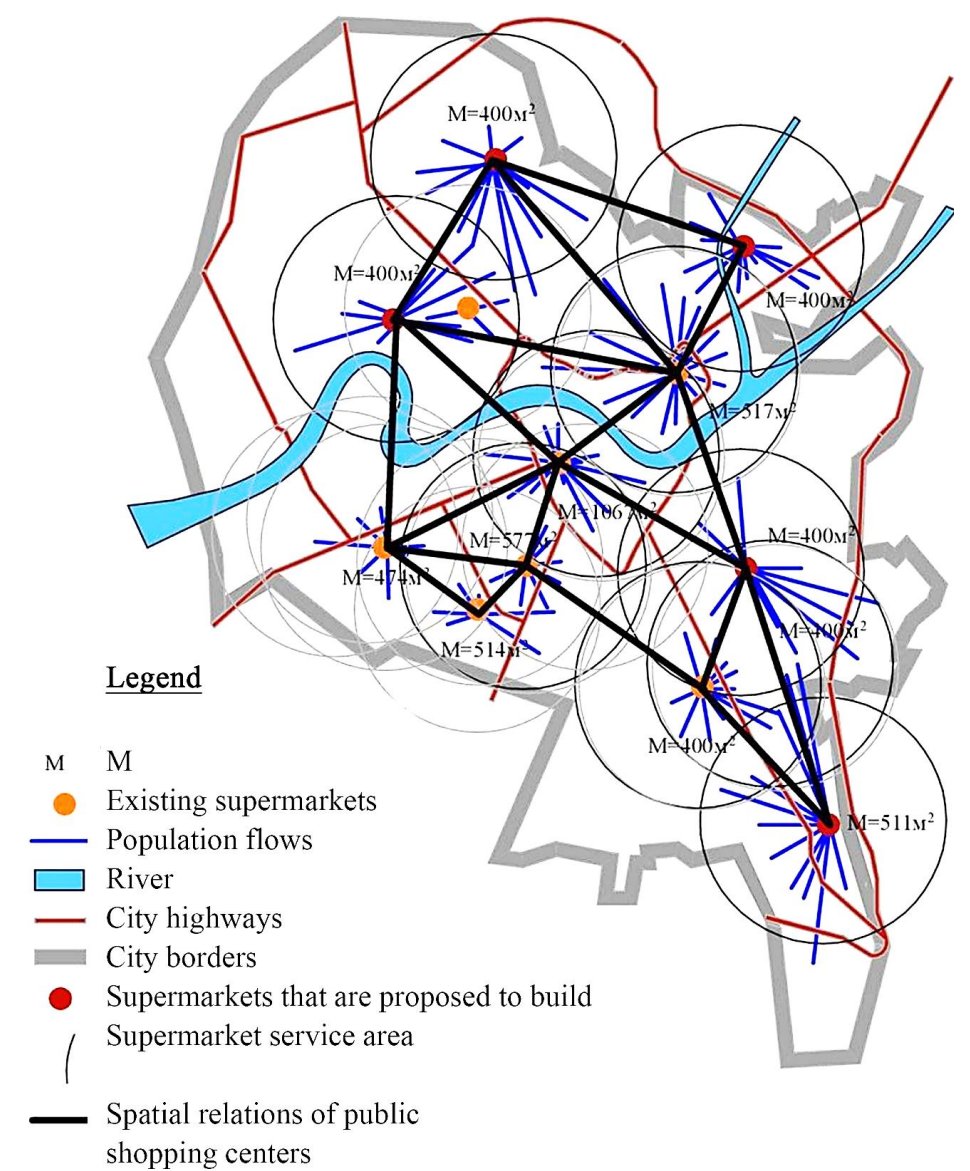

Fig. 13. The information model of a network of public shopping centers in Uzhhorod 
At the second stage, modeling of the distribution of population flows is performed.

The third stage involves evaluating the work of each center column. All the necessary data for the assessment obtained at the first and second stage of this algorithm.

At the fourth stage, proposals are made to improve this category of service based on the assessment.

After making suggestions for improving the public services network of the city, the transition to the first stage of this flowchart takes place. The network graph is modified taking into account the proposed measures for the improvement and enumeration of the changed network elements.

Taking into account the above, general recommendations are formed on improving the socio-planning structure of the city (Fig. 14).

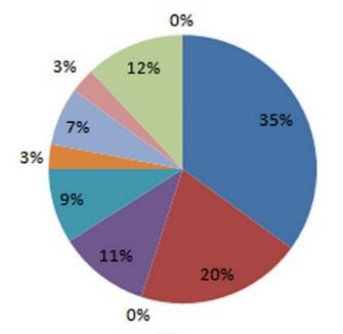

$2 \%$
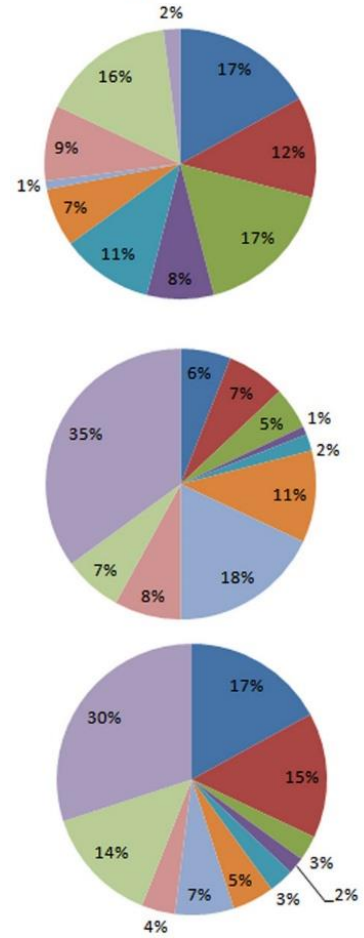

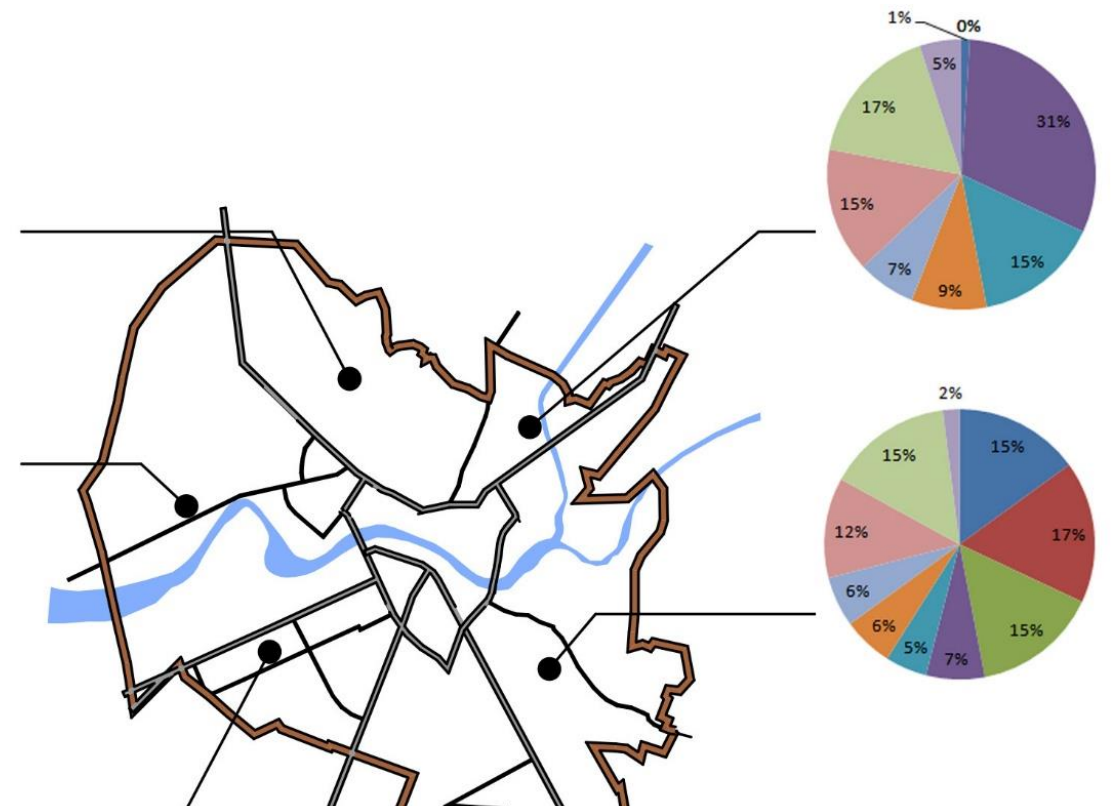

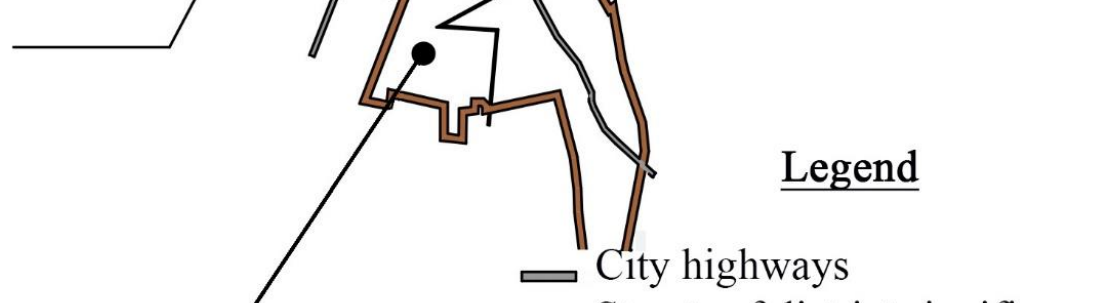

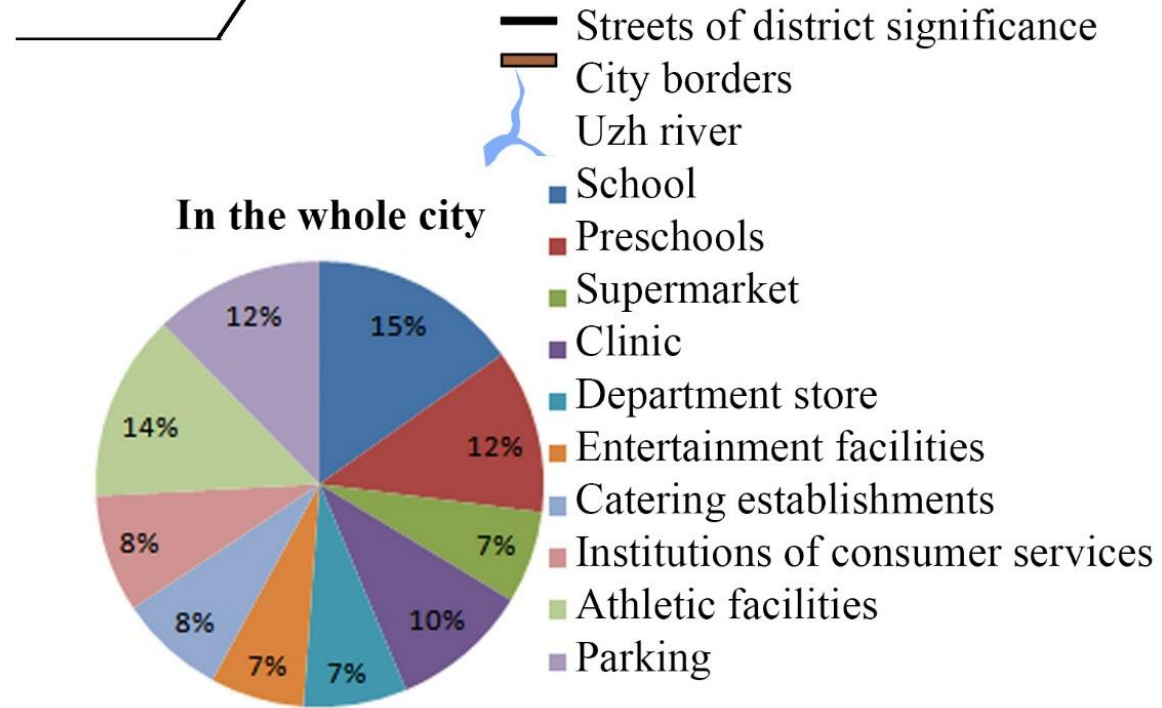

Fig. 14. The study of demand for public services in Uzhgorod 


\section{Conclusions}

Using the graph-analytical method for modeling the public services sector, as well as the socio-planning structure, the following shortcomings are identified: insufficient radius of accessibility of service facilities in peripheral areas where the building density is insignificant, imperfection of the functional organization of public centers; the concentration of the overwhelming number of public functions at the intersections of traffic flows; significant density of such intersections in the territory in the central part of cities, and at the intersections of city highways and the like.

That is why the future development of the socio-planning structure should take place against the background of a clear structuring of traffic flows with the subsequent linking of the public sphere and the corresponding structural units of the city. Only in this case it is possible to optimize the existing network of cultural services. In the course of research is:

1. Systematization of options for the placement of public centers of the city (on the example of Uzhhorod) in relation to residential groups, and their analysis. The systematization of the layout options for microdistricts and the economic analysis of these options have been performed.

2. The effectiveness of the proposed model for optimizing the structure of public services is verified using the example of a grocery store chain - supermarkets. The calculation is carried out by the method of social potential, and also using the graph-analytical method in determining the optimal location of service facilities. As a result, a layout of supermarkets on the territory and distribution of service areas of these institutions is proposed. Similar studies are conducted by "A+C Ukraine" to develop a transport model of Kyiv and its suburban area using the PTV VISUM software package. The model of the transport proposal for Kyiv is obtained using the Open Street Map geographic information resource (OSM - "open street map") - this is a non-commercial web-cartographic project to create a free geographical map of the world. After importing OSM into PTV Visum, the transport network was carefully checked and adjusted. These results show that the optimization carried out will provide uniform consumer services for the territory of both Uzhhorod and Kyiv, taking into account the optimal performance indicators of service facilities and the minimum average service radius of the points.

3. It is determined that the presented method for modeling service facilities in residential quarters allows to calculate the existing socio-planning organization in the field of: kindergartens, schools, physical education and sports facilities, cultural and leisure facilities, community hospitals and polyclinics, relying on traffic flows. This approach allows to obtain basic indicators for the development of an integrated socio-planning model based on transport modeling in order to improve public services in any studied city.

\section{References}

[1] Domin, M. M., Mishchenko, O. D. (2010). Pervynnyi element sotsialno-planuvalnoi struktury krupnoho mista - mikroraion. Mistobuduvannia ta terytorialne planuvannia, 37, 138-139.

[2] Synhaivska, O. I., Orel, A. A. (2011). Sotsialno-planuvalni aspekty proektuvannia, rekonstruktsiyi ta blahoustroiu selbyshchnykh terytoriy. Mistobuduvannia ta terytorialne planuvannia, 40, 328-339.

[3] Holyk, Y. M., Kis, N. Yu. (2012). Evoliutsiya planuvalnoi struktury mista. Mistobuduvannia ta terytorialne planuvannia, 46, $160-164$.

[4] Kis, N. Yu. (2012). Rozrobka metodiv orhanizatsiyi systemy obsluhovuvannia serednoho mista. Mistobuduvannia ta terytorialne planuvannia, 43, 134-138.

[5] Osetrin, N. N., Bespalov, D. O., Hagen, A. S., Kutsyna, I. A. (2018). Research of mobility of the city population on the example of Uzhgorod city. Mistobuduvannia ta terytorialne planuvannia, 68, 409-419.

[6] Kutsyna, I. A. (2018). The role of functional-planning structure in the formation of the pedestrian-communication framework of the city. Mistobuduvannia ta terytorialne planuvannia, 66, 354-359.

[7] Kablak, N., Nychvyd, M., Moish-Shiman, P., Gurchumelia, U. (2018). To the question of territorial planning of the transboundary territory of Ukraine-Romania. Mistobuduvannia ta terytorialne planuvannia, 67, 584-590.

[8] Apel, M. (2004). Simulation of pedestrian Flows based on the Social Force Model Using the Verlet Link Cell Algorithm. Poznan University of Technology, 79.

[9] Mehran, R., Oyama, A., Shah, M. (2009). Abnormal crowd behavior detection using social force model. 2009 IEEE Conference on Computer Vision and Pattern Recognition. doi: https://doi.org/10.1109/cvpr.2009.5206641 
[10] Wąs, J., Gudowski, B., Matuszyk, P. J. (2006). Social Distances Model of Pedestrian Dynamics. Cellular Automata, $492-501$. doi: https://doi.org/10.1007/11861201_57

[11] Büttner, T., Schwager, R., Stegarescu, D. Agglomeration, Population Size, and the Cost of Providing Public Services: An Empirical Analysis for German States. Discussion Paper No. 04-18. Available at: ftp://ftp.zew.de/pub/zew-docs/dp/dp0418.pdf

[12] Frère, Q., Hammadou, H., Paty, S. (2011). The range of local public services and population size: Is there a "zoo effect" in French jurisdictions? Dans Recherches économiques de Louvain, 77, 87-104. doi: https://doi.org/10.3917/rel.772.0087

[13] Álvarez-Ayuso, I. C., Condeço-Melhorado, A. M., Gutiérrez, J., Zofío, J. L. (2014). Integrating Network Analysis with the Production Function Approach to Study the Spillover Effects of Transport Infrastructure. Regional Studies, 50 (6), $996-1015$. doi: https://doi.org/10.1080/00343404.2014.953472

[14] Crainic, T. G., Ricciardi, N., Storchi, G. (2009). Models for Evaluating and Planning City Logistics Systems. Transportation Science, 43 (4), 432-454. doi: https://doi.org/10.1287/trsc.1090.0279

[15] Brilon, W., Hartmann, D. (2004). Fortentwicklung und Bereitstellung eines bundeseinheitlichen Simulationsmodells für Bundesautobahnen. Research project FE01/157/2001/IRB for the Bundesanstalt für Straßenwesen (Federal Highway Research Institute, Germany), in cooperation with the Ruhr-University Bochum.

[16] Bundesministerium für Verkehr, Bau- und Wohnungswesen (BMVBW). (2004). Neubau von Bundesautobahnen.

\title{
SCRATCH LANGUAGE OF PROGRAMMING VS ENGLISH LANGUAGE: COMPARING MATHEMATICAL AND LINGUISTIC FEATURES
}

\author{
Nataliia Lazebna ${ }^{l}$ \\ natalialazebnaya@gmail.com \\ Yuliya Fedorova \\ Department of English Language \\ Mariupol State University \\ 129 a Budivelnykiv ave., Mariupol, Ukraine, 87500 \\ julfedorova84@gmail.com \\ Mariia Kuznetsova ${ }^{1}$ \\ kuznetsovamariaalexandrovna@gmail.com \\ ${ }^{1}$ Department of Theory and Practice of Translation \\ National University "Zaporizhzhia Polytechnic" \\ 64 Zhukovskogo str., Zaporizhzhia, Ukraine, 69061
}

\footnotetext{
Abstract

This paper focuses on Scratch language of programming and traces its math and linguistic features. From a complex consideration about Scratch language programming in linguistic paradigm, focusing on structural, semantic and syntactic features and logic of its narration, this research attempts to clarify specifics of the language and correlate it with the English language features. Global integration of ideas and sciences underline the crucial importance of programming and language conglomerate. Human-computer interfaces, software systems, and development of various programming languages depend on well-balanced structure, shape, logic, and appearance of the actual code. Dynamic characteristics of the Scratch programming environment sustain the creation of interactive and media-rich projects. Ad expansion of Scratch for mediation of animated stories, music videos, science projects, tutorials, and other contents necessitates multifaceted analysis of this programming environment and evokes
} 